\title{
Radicalization: The Misconception of Religious Practices in Diversity
}

\author{
Siti Komariah ${ }^{1^{*}}$ \\ ${ }^{1}$ Department of Sociology Education, Faculty of Social Science Education, \\ Universitas Pendidikan Indonesia, Bandung, Indonesia \\ Jalan Dr. Setiabudi No. 229, Isola, Sukasari, Bandung, Jawa Barat, Indonesia \\ Email: sitikomariah@upi.edu
}

\begin{abstract}
Diversity is a necessity that cannot be denied by anyone, diversity that is based on true differences should be responded to with an attitude of tolerance and view that all differences are the nature of life. However, a handful of people in the name of religion actually see diversity as a threat that is very counter to their views so that with the frontal dare to call for war against these differences. Diversity and religious life is a concept that not only cares for fellow human beings but also respects and protects what God has created as a form of obedience. Seeing from a number of radical groups acting in the name of religion and carrying out extreme actions, this article seeks to reveal how Islamic organizations view the problem. By using a qualitative approach and phenomenology technique, which was carried out through in-depth interviews with 5 informants with the background of the organization's organizers it was found that there were three phases of a person behaving radically. But in this article more emphasis on the first phase, namely sensitivity, because this phase is seen as a channel for the formation of radical ideology in a person. Expected implications, social awareness can be formed that radicalism can actually be prevented from the beginning, with the right approach and method, as described in this article.
\end{abstract}

Keywords: diversity, religious practice, radicalization

\begin{abstract}
Abstrak
Keberagaman merupakan suatu keniscayaan yang tidak dapat dipungkiri oleh siapapun, keberagaman yang sejatinya dilandasi dengan perbedaan seharusnya di tanggapi dengan sikap toleransi dan memandang bahwa segala perbedaan merupakan fitrah kehidupan. Namun, segelintir orang yang mengatasnamakan agama justru memandang keberagaman tersebut sebagai ancaman yang sangat kontra dengan pandanganpandangan mereka sehingga dengan frontal berani untuk menyerukan perang terhadap perbedaan tersebut. Keberagaman dan keberagamaan merupakan suatu konsep yang bukan hanya peduli kepada sesama umat manusia tetapi juga menghargai dan melindungi apa yang telah diciptakan tuhan sebagai bentuk dari ketaatan. Melihat dari beberapa kelompok radikal yang mengatasnamakan agama dan melakukan tindakantindakan ekstreem tersebut artikel ini berusaha mengungkap bagaimana pandangan ormas Islam dalam menyikapi permasalahan tersebut. Dengan menggunakan pendekatan kualitatif dan tekhnik fenomenologi, yang dilakukan melalui wawancara mendalam kepada 5 narasumber dengan latar belakang pengurus ormas tersebut, didapatkan
\end{abstract}


bawah terdapat tiga fase seseorang berprilaku radikal tersebut. Namun dalam artikel ini lebih menekankan kepada fase pertama yaitu sensitifitas, karena fase ini dipandang sebagai gerbang terbentuknya faham radikalisme dalam diri seseorang. Implikasi yang diharapkan, dapat terbentuknya kesadaran sosial bahwa radikalisme sejatinya dapat dicegah sedari awal, dengan pendekatan dan cara yang tepat, seperti yang digambarkan dalam artikel ini.

Kata kunci: keberagaman, keberagamaan, radikalisasi.

\section{INTRODUCTION}

Within a period of 10 years the world was stirred up by various kinds of terrorism attacks in the name of religion, moreover they seemed to justify understandings that were not necessarily true. They use the pretext of religion as a shield that their radical actions are justification of the discrepancy with what they think (Doosje, Moghaddam, Kruglanski, de Wolf, Mann, and Feddes 2016). Radicalization in the name of religion has become the main focus in the fight against radicalism throughout the world (Neumann, Arendt, and Baugut 2018). As a result, several countries have arrested and detained perpetrators of acts of radicalism, especially those related to terrorism. The challenge for governments in the world is how to ensure that radicalism does not occur in a sustainable manner and can be preventive handling.

However, some countries use a more humane approach to confronting radicalism in order to have a long-term effect on actors. Some of them recognize that the fight against extremism requires an ideological dimension (Cohen, Kruglanskib, Gelfand, Webber, and Gunaratna 2018). Previous research says that cracking down on radicalism actors requires a good understanding to be able to counter these deviant ideologies so that they can return to live with society normally. The approach consists of a de-radicalization program that focuses on rehabilitation that targets incarcerated extremists (Kruglanski, Gelfand, Bélanger, Sheveland, Hetiarachchi, and Gunaratna 2014). The main focus of the approach is that radicators have been led astray by their recruiters and, as a result, harbored a misconception about something they think is right. Rehabilitation is a possible solution to the problem of prisoners of detainees with suspect status. Also, prisons are ideal locations for de-radicalization programs because of the control measures that can be applied in prison settings. 
Komariah: Radicalization: The

Misconception of Religious Practices in

Diversity

A study of imprisonment for global radical offenders reflects that around $15 \%$ of these radical offenders receive a death sentence or life imprisonment, while others receive 20 years or less or 10 years or less (Speckhard and Jkovci, 2018). The majority of these jihadists are often released even earlier through disproportionate ranking of recidivism among extremists who are freed according to one scholar's view (Klausen, Libretti, Hung, and Jayasumana 2018). For example, an examination of radical cases released from Moroccan, Yemen, Algeria, and Egyptian prisons found that many former prisoners carried out terrorist attacks and suicide bombings after their release (Klausen, Campion, Needle, Nguyen, and Libretti 2016).

However, if examined, the actual prison can be a place for seeding and the proliferation of radical ideas because they seem to be united in the same place (Arshad-Ayaz and Naseem 2017). Many prisoners then become radical thinkers because of the stimulus both in the environment inside the prison and during interrogation because of the way. violent and torture of detainees. (Eerten, Doosje, Konijn, Graaf, De, Colophon, and Doosje 2017).

Deradicalization programs have been used in various places, such as Algeria and Egypt, but these target extremist groups rather than individuals. In addition, the main component of these programs is the heavy use of repression rather than attempts to change ideology (Doosje et al. 2016). Deradicalization through rehabilitation is a relatively new concept for dealing with radical perpetrators who are incarcerated. At present, little information is available to evaluate the overall effectiveness of the program (Jensen, Seate, and James 2018). The process of deradicalization tries more than just breaking away from terrorist groups. Although there is a lot of research that exists about what causes radicalization, some research has been done on what factors cause a person to deradicalise. However, a lot of research has been done about the release of other anti-social organizations, such as street gangs, right-wing extremist groups, and other terrorist groups.

Deradicalization programs consist of approaches that are more focused on prisoners who have extreme ideologies. One approach is to change extremist thinking about things that they consider to be true but are major mistakes in society, such as murder, vandalism, and rape. Another approach is to change the 
pattern of their interactions and further distance them from the previous environment. And the third approach is to help reintegrate individuals into normal society (Eerten et al. 2017). Previous research shows deradicalization efforts through prison-based rehabilitation programs that focus on individual extremists. Countries such as Saudi Arabia, Yemen, Indonesia and Singapore have received much publicity about their latest programs aimed at radicalizing and rehabilitating individual militants (Crone 2016).

The de-radicalization program gave rise to a new discourse on the prevention of radicalism by focusing on the countries with the largest number of Muslims such as Indonesia. Because, from a demographic point of view, Indonesia has the potential to become the most peaceful Muslim country, given that it is not only religion that is diverse but also culture that is widespread. However, it cannot be denied that Islam in Indonesia is often divided by several groups (McCauley and Moskalenko 2008).

The novelty of this research is on the research subjects who are the leaders of large Islamic organizations in Bandung. The bombing case that occurred in Surabaya and addressed to the church more or less tarnished the good name of Muslims throughout Indonesia, further aggravated who became the perpetrators of the bombers are still the same family. So that raises questions about how the process of preventing radicalism in this case Islamic extremists so that similar incidents do not happen again in the future. Indonesia as a country with the largest number of Muslims in the world certainly has its own way of de-decalalizing similar events. However, in Indonesia there are several large groups with Islamic backgrounds. In this article the emphasis is on the pattern of Islamic organizations in providing a counter finalty to the case of radicalism in Indonesia. It is hoped that the prigram can be useful in handling radicalism in the future.

Theoretical framework radicalization is often interpreted as a process in which groups or individuals are socialized to certain world views that are considered radical or extreme. Like the literature on terrorism or academic literature on radicalization. However, some definitions of radicalization are so broad as to categorize that all opinions differ from social norms. Another definition mixes radicalization with a tendency or support for the use of violence as a legitimate way to achieve goals. But in essence, radicalization is a process in which people become increasingly motivated to use methods of violence against 
Komariah: Radicalization: The

Misconception of Religious Practices in

Diversity

members of a target outside the group or symbolic to achieve changes in behavior and political goals. In Figure 1, the radicalization (and deradicalization) model is described. Inspired by the 'staircase model to terrorism', this model distinguishes three phases. Phase 1 is characterized by sensitivity to radical ideology. In Stage 2, an individual becomes a member of a radical group. Finally, in Phase 3, this person is ready to act on behalf of the group's ideology, for example by planning an attack (Khosrokhavar 2017).

Figure 1

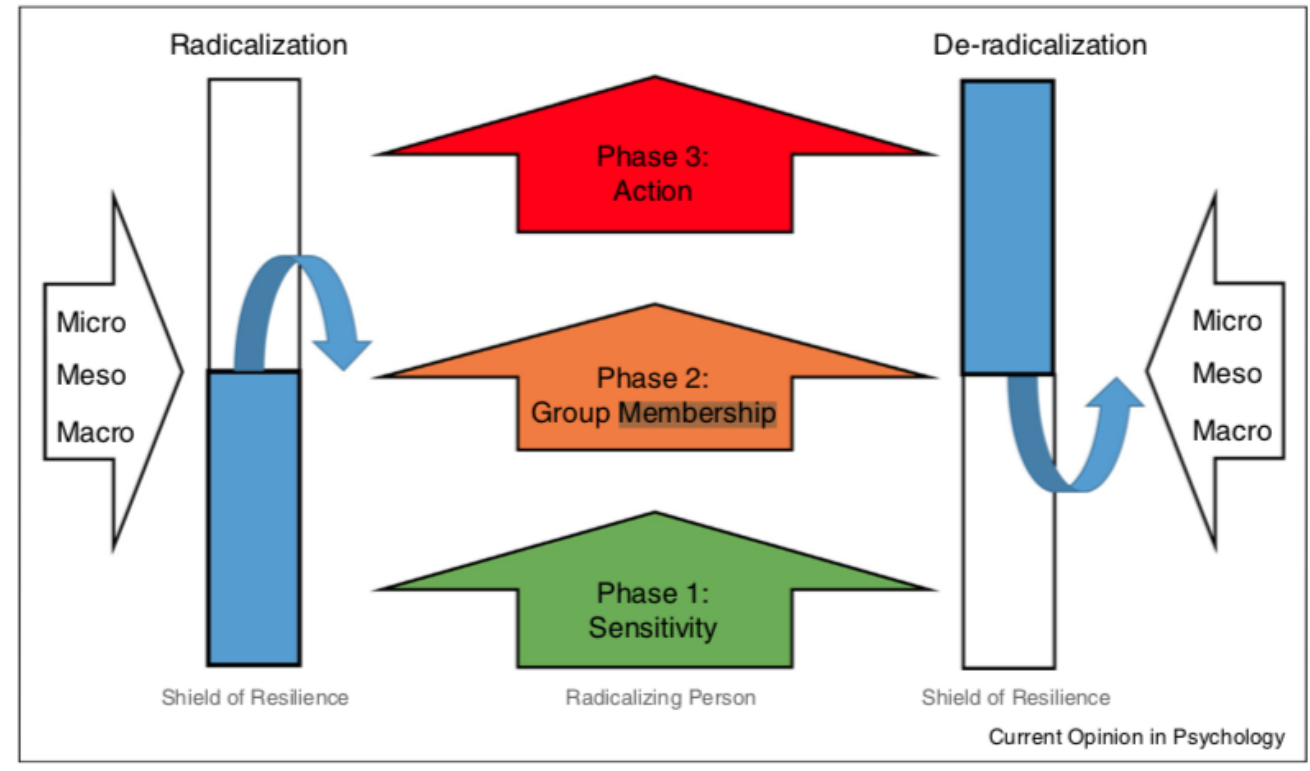

The (de)radicalization process and its determinants (Doosje et al., 2016)

There are 5 types of radical groups that can be distinguished. Table 1 describes these types and shows what their main concern is: 
Table 1

\begin{tabular}{|c|c|c|}
\hline Type & Main Concern & Example \\
\hline $\begin{array}{l}\text { Nationalistic or Separatist } \\
\text { Group }\end{array}$ & $\begin{array}{l}\text { Scure a teritory for the own } \\
\text { group }\end{array}$ & $\begin{array}{l}\text { Gerakan Papua Merdeka } \\
\text { (Indonesia) }\end{array}$ \\
\hline $\begin{array}{l}\text { Extreme } \quad \text { Right-Wing } \\
\text { Groups }\end{array}$ & $\begin{array}{l}\text { To safe-guard the high } \\
\text { status position of the "white } \\
\text { race that is percived to be } \\
\text { threatebed by immigrants }\end{array}$ & $\begin{array}{l}\text { Klu Klux Klan (U.S.), } \\
\text { Pegida (Germany) }\end{array}$ \\
\hline Extreme Left-Wing Groups & $\begin{array}{l}\text { Achieve a just distribution } \\
\text { of whealth and percieve } \\
\text { capitalism as the main } \\
\text { source of evil }\end{array}$ & $\begin{array}{l}\text { FARC (Colombia), Baader- } \\
\text { Meinhof Group/'Red Army } \\
\text { Fraction' (Germany), the } \\
\text { Red Brigade (Italy), the } \\
\text { Revolutionary People's } \\
\text { Liberation Party-Front' } \\
\text { (Turkey) }\end{array}$ \\
\hline Single issue Groups & $\begin{array}{l}\text { Their main concern focuses } \\
\text { on one particular topic (No. } \\
\text { an extensive ideology), } \\
\text { such as the environment, } \\
\text { animal rights or abortion }\end{array}$ & $\begin{array}{l}\text { 'Earth Liberation Front' } \\
\text { (U.K.), 'Animal Liberation } \\
\text { Front' (several countries), } \\
\text { 'Army of God' (Anti- } \\
\text { Abortion, U.S.) }\end{array}$ \\
\hline $\begin{array}{l}\text { Religiously } \\
\text { groups }\end{array}$ & $\begin{array}{l}\text { They adhere to a very strict } \\
\text { interpretation of their } \\
\text { religion to justify violence } \\
\text { against 'infidels' }\end{array}$ & $\begin{array}{l}\text { ISIS (Syria/and Iraq), Al } \\
\text { Qaida (several countries), } \\
\text { 'Army of God' (U.S.) }\end{array}$ \\
\hline
\end{tabular}

5 Types of radical groups (Doosje et al. 2016)

Different types of radical groups, their main concern and examples.

Different types of radical groups share common elements (Soliman, Bellaj, and Khelifa 2016). First, all radical groups feel a serious problem in society. These problems or complaints are different for each radical group - see Table 1 for an example. Second, radical groups are very dissatisfied with the way in which current institutions (mainly police / politicians) handle their problems. They might argue that institutions do not pay enough attention to their complaints, or they may think that institutions are not enough to handle their complaints. This creates low institutional trust and the perception that authority is illegitimate. The third important characteristic of radical groups is that they regard the norms and values of their own groups as superior to other groups. This creates a strong distinction between us, which may form the basis of the use of violence. The characteristics of the four radical groups are very important: most of them accept an ideology 
Komariah: Radicalization: The

Misconception of Religious Practices in

Diversity

that legitimizes violence to address their concerns, and this violence is often directed at outside groups that are considered to be the perpetrators responsible for creating complaints. This is most clearly articulated in the application of social identity theory to radicalization, where identification with an inner group is combined with identification with an outside group related to the use of violence against group members (Sheffield 2016).

Related to these five radical groups is the strong belief that the use of violence is the only way to deal with problems in society. As a result, radical groups tend to recognize the violence committed by their members as the most effective way to achieve their ideological goals.

\section{METHODS}

The approach taken in this article uses quality with a focus on phenomenological methods, the reason for using that method is to interpret understanding of radicalism from the point of view of Islamic organizations, understanding here is an experience not experienced directly by the speakers but their point of view about phenomena that occur in the field, because basically radicalism or radicalization is a social act that results from dissatisfaction with certain matters, or other meanings will appear in accordance with the interpretations of each source. The data collection technique that was carried out was interview technique which was carried out directly in the office of one of the Islamic organizations that was in Bandung considering that Bandung was one of the biggest bases of the organization in Indonesia. Interviews were conducted to 5 religious teachers / Kiyai by making an agreement in advance for interviews conducted to obtain holistic and constructive results. Interview questions are the result of the development of previous literacies related to similar problems, which are based on how radicalism can occur and how the solution to deal with this phenomenon, there are three main indicators in the interview questions about radicalism, namely: 1. Sensitivity, 2. Membership, 3. Actions. From the three phases the researcher tries to dig deeper into why these phases can become a trigger to a more extreme level. In this article, it will be explained in the first phase, which is the sensitivity phase, because it is seen as a channel for the formation of deviant ideologies and the source of action - extreme actions. 
Radicalization in Islamic organizational views. Broadly speaking, the Islamic organizations we interviewed do not yet have a definite sequence of how the process of de-radicalization is carried out so that perpetrators who are victims here can be "cured" of wrong understanding and intolerance towards something. According to the informant, it was mentioned that terrorism which is described as part of an act of radicalism contains understandings which are precisely the negation of religious understanding itself, in this case the religion of Islam, in any verse no action is found to force the creed for certain interests. Radicalism that occurs is the result of indoctrination of religious actions that are mistaken and can be interpreted as acts of pollution against religious life itself (Campbell and Jansen 1980). If seen from the three phases of radicalism, sensitivity or the first phase is the most crucial phase because this is where one can be attracted or consumed by deviant doctrines, but the need for someone to enter deviant ideologies is due to other factors within the individual itself between other, feelings are not accepted or excluded from the social environment, feelings of insignificance can be caused by loss of status, strong humiliation, or bad career prospects (personal failure, criminal activity, and drug abuse). Radical groups such as ISIS are well equipped to grow or restore important feelings by providing recruits with a sense of belonging, respect, heroism, status and ideas to fight for sacred goals (Greenberg 2016).

The second important driving factor at the micro level is selfmisconception. When people feel unsure, they become motivated to identify strongly with groups that reduce their uncertainty by giving them clear norms and values. Radical groups are mainly able to do this, because they have a clear profile, offering a solid structure and a black-and-white worldview (Kruglanski, Jasko, Webber, Chernikova, and Molinario 2018). Thus, orthodox groups, such as the Jihadists, with well-developed rules of conduct can appeal to people who experience personal uncertainty.

At the meso level, the process of radicalization tends to depend on the social environment (friends, family, and other groups). Important driving factors at this meso level are the relative deprivation of brotherhood, the feeling of discomfort people experience when they identify with their group and feel that their group has been treated worse than other groups (Webber and Kruglanski 2018). For example, Muslims in Europe experience this in terms of housing, 
Komariah: Radicalization: The

Misconception of Religious Practices in

Diversity

educational opportunities, employment and income. In addition, they experience discrimination and use of double standards from the media. Likewise, right-wing groups experience that indigenous people are treated worse than immigrants (Doosje et al. 2016).

Another important factor at the meso level is friendship and family. Humans are social creatures and this makes them vulnerable to the social influences of people who are close to them and with whom they are often associated. This also applies to Jihadi warriors. Extremist groups provide individuals with a strong sense of belonging in a group, which is a basic human need, and a clear picture of an evil group, creating dynamic between strong groups (Doosje et al. 2016).

Radicalization as rebellion to social structure. Looking at radicalism cannot be denied that it is something that has a negative connotation and has the potential to disrupt social structures that have existed for a long time. From the point of view of the world community, radicalism has always been interpreted as a thing that erases, destroys, and gives a very deep traumatic effect for both victims and perpetrators (Ferguson and McAuley 2019). In sociology we recognize actions that are not in accordance with the values and norms prevailing in the community as a social deviation. But how can this thought arise? In this radical type deviation arises because of a different understanding of a value so that the understanding is considered to be the most correct but irresponsible method of delivery (Sieckelinck, Sikkens, San, Kotnis, and Winter 2017). Besides this factor the emergence of social deviation is caused by a textual understanding model that makes a person or group narrow-mindedly who only sees from the point of view of what they are reading, and denies other views as a form of reference reference for the behaviors they will appear (Borum and Patterson 2019). Deviation and radicalization of the textual understanding enables a person to experience a conflict of values in their lives. The impact of these value conflicts can lead to fear, anxiety and frustration that settles on their souls. These things then bring up three kinds of attitudes namely, rigidity, aggressiveness, and schizophrenia (Holt, Freilich, Chermak, Mills, and Silva 2019).

In general the attitude or behavior rigidity will bring up an exclusive attitude. These attitudes will lead to psychological deviations, where they are not 
able to adapt to the environment that they think is different, radiklian will think that people outside their understanding are the most wrong people and will continue to be blamed as long as they do not have or behave the same as the radikalian (Kruglanski et al. 2014).

Just as an understanding of a doctrine that is carried out excessively without prioritizing other thoughts will usually lead to this attitude, they will feel that they are the most correct, they are the most entitled to this world and as if to be the most understanding how humans should behave accordingly with the teachings they profess. Psychologically their actions are considered abnormal or sociologically referred to as deviants, because individuals in radical groups are not able to think logically and realistically in interpreting events that occur in society. The in linearity of the thought then raises an attitude of intolerance towards other views where the thought will alienate them from the values of diversity that already exist in the world community, especially the people of Indonesia (Misiak, Samochowiec, Bhui, Schouler-Ocak, Demunter, Kuey, Dom 2019).

It can be concluded that the attitude of rigidity and exclusiveness arises due to a belief that the values they profess are considered the most correct. However, what is the basis for someone to do radicalism? In some cases it is stated that radicalism is the result of a continuing conflict of values in a person who then invites others both voluntarily and coercively to have the same values, but in essence they are a minority group with distorted thinking who try to restructure social order according to the values they profess (Ahmad and Monaghan 2019). However, in reality these values are not in accordance with the ideal values that have been previously structured in society, so that the conflict of values is getting harder which leads to frustration and results in the emergence of an aggressive attitude of radicalism.

Another perspective which is attempted to be elaborated in the findings on radicalism is the existence of excessive democratic thinking without being accompanied by an understanding of how to actually act democratically. This can give birth to a simplistic stigma which then will easily lead to emotional attitudes because of a lack of a thorough understanding of the problem at hand. For example, the rise of actions that are considered intolerance is a negation of selftolerance (Bos 2020). There is no longer a limit between tolerance and neglect, as if the community lived without values that originated in the culture, religion, and 
Komariah: Radicalization: The

Misconception of Religious Practices in

Diversity

characteristics of the multicultural society itself. The label of intolerance illustrates that the reality of values, norms, and culture is imaginary and is artificial. Being intoxicated by tolerance can lead to conflicts both horizontally and vertically, because people become groups with their respective understandings, this is where triggers of radicalization, where thinking that overrides multiculturalism in a country that has many cultures and other things can trigger friction between ethnicities, cultures, as well as religion. Especially if this is not handled in a structured manner, conflicts between ideologies will occur and create divisions.

So it can be concluded that radicalism is a thought and attitude arising from value conflicts that arise due to tension. As well as radicalism is an attitude that arises from the inability to adapt to the environment in which a handful of people or groups live in it, they tend to be apathetic and as if to change the existing social structure.

Radicalism: the misconception of religious practices in diversity. Indonesia is known as a country that has many uniqueness, such as culture, race, ethnicity, and religion. In the last few decades, diversity in Indonesia has experienced various shocks such as the ethnic conflict that has occurred in several regions (Fuad 2004). However, what is most worrying is the feud between religions, this happened and almost resulted in divisions between religions. The Indonesian state is dominated by the religion of Islam, since the past the majority appreciated the existence of a minority and considered no difference among humankind. however, debates began to emerge when religious teachings were used as an excuse to gain votes in the political arena (Pemberton 1952). The politicization of religion that has happened is very bad for religious life amid diversity (Schwartz 2016). The strategy seems to deny that Indonesia is a country that is not only multi-religious but also multi-ethnic. The politicization of religion will only bring up small groups in the name of religion to achieve their interests.

In practice, these small groups will consider the ideology of the group which holds the best ideology, so that ideologies that are considered as contradictory as possible will be eliminated, the situation can trigger horizontal conflicts between groups by naming certain religious ideologies (Porta 2018). This is where misconception in the midst of diversity arises, they no longer look 
at multiculturalism adopted by Indonesia, prioritizing group ideology to achieve interests is seen as the main thing. Horizontal conflict seems to be handled after they achieve this. Seeing this situation makes us think that multicultural education taught from an early age does not have any impact if it is confronted with interests. The role of educators which is a central role in humanizing humans is faced with a dilemma that maintaining diversity in diversity requires a complete focus, for what multicultural education is carried out (Sharma and Monteiro 2016).

Multicultural education is basically the concept and practice of education that puts forward the values of equality without looking at differences in cultural, socio-economic, ethnic, religious, gender, etc. (Alamilla, Kim, Walker, and Sisson 2017). All people have the same opportunity to obtain the right to education. With the application of multicultural education, it is hoped that exclusive enthusiasm and self-righteousness as a cause of conflict with others can be avoided. A true multiculturalist is a person who is always tolerant, appreciates the existence of others without losing his own identity (Fortier 2008). If the ultimate goal of education is a change in behaviour and attitudes and qualities of a person, then teaching must take place in such a way that it does not merely provide information or knowledge but must touch the heart, so that it will encourage students to make decisions to change. In addition to aiming to strengthen religious education in religious beliefs, must also be oriented to instil empathy, sympathy and solidarity with others.

As explained earlier, that multicultural education is a step to eliminate exclusivity in terms of religion and culture. This exclusive attitude can lead to thoughts to master and apply their ideologies to people who are not in any way, and will often lead to radical actions, in this case we can analyze through the stages of radicalism, namely, the stage of sensitivity, membership, and actions. At the first level of sensitivity, what this process can influence is at the micro level, which involves seeking significance, such as feelings of insignificance that can be caused by loss of status, strong humiliation, or bad career prospects (personal failure, criminal activity, and drug abuse). This happens to radical groups like ISIS who try to change a person's mind and try to grow and restore feelings, so that a sense of belonging, respect, heroism, status and ideas to fight for the sacred goals of their members (Doosje et al. 2016). 
The second factor at the micro level is personal uncertainty. Where someone will feel unsure, who then tries to identify groups that reduce their uncertainty through the provision of clear norms and values. This can be done by radical groups, who try to show a clear background, and try to form a solid structure and black-and-white perspective of the world. Therefore, the orthodox group, like the Jihadi group, will offer an interesting code of behaviour to a group of people who experience self-doubt. Then at the meso level, the process of radicalization will continue to depend on the closest social environment (friends, family and other groups). An important motivating factor at this meso level is the relative deprivation of fraternity that is formed, due to an uncomfortable feeling in someone when their group has been treated worse than the other group. For example, the experience of Muslims in Europe who experienced exemptions from themselves in the home environment, as well as difficult educational, employment and income opportunities. What's worse, they get discrimination from the double standards set up by the media. The same thing happened with the right wing group, that the native people were treated worse than immigrants (Doosje et al. 2016).

Another important factor at the meso level is the meaning of friendship and family. Humans are social creatures who naturally have a sense of dependence and with other closest people. This also applies to Jihadi warriors. Extremist groups that commit crimes, they try to form each individual to have a strong sense of loyalty to a group and uphold a high dynamics of friendship (Kruglanski et al. 2014).

\section{CONCLUSSION}

Diversity and diversity are actions that are quite difficult to do given the many other interests that can damage the social order of diversity. Radical action is an act that always overshadows that the means of violence to achieve certain goals is a justification when the alignment of ideology by gentle means is not achieved. The diversity that a country actually has must be seen as something amazing because in diversity it will lead to an attitude of tolerance and mutual cooperation. However, in practice excessive tolerance has also threatened diversity itself, because people have begun to generalize that religion, ethnicity, 
and culture are the same thing, this is not at all justified. The cultivation of universal values in multicultural life must pay attention to aspects and values contained in each culture so that misconceptions do not occur in social life.

Tackling radicalism is a structured and systematic work, deviant actions in the name of religion cannot only be resolved through one approach, but requires multidisciplinary knowledge, most of the time handling radicalism is only cantered on certain religions and even more discrediting religious teachings in this case the most disadvantaged is the religion of Islam. The existence of terrorism and radicalism actually results from the dissatisfaction of individuals who are gathered into a group with an extreme ideology with the aim of overthrowing part or all of the powers that are considered not in accordance with the teachings or doctrines they have received. Handling the case is no longer on the rehabilitation order but it has been a re-doctrination stage so that the teachings they receive can be erased from their brains, in short brainwashing back to get back on the right path. In the Indonesian context, these radical members, or so-called extremists, must be given a re-understanding that the diversity that exists in Indonesia is a gift from the Almighty and part of religious teachings to be able to look after one another and love one another. Weak attitude of tolerance or easily weakened the attitude of tolerance in part of Indonesian society is a big job not only the government but all Indonesian people to equally be able to maintain and protect the diversity and harmonization of community life.

\section{REFERENCES}

Ahmad, F. and J. Monaghan. 2019. Mapping Criminological Engagements within Radicalization Studies. British Journal of Criminology, 59(6), 1288-1308. https://doi.org/10.1093/bjc/azz023

Alamilla, S. G., B. S. K. Kim, T. Walker, and F. R. Sisson. 2017. Acculturation, Enculturation, Perceived Racism, and Psychological Symptoms Among Asian American College Students. Journal of Multicultural Counseling and Development, 45(1), 37-65. https://doi.org/10.1002/jmcd.12062

Arshad-Ayaz, A. and M. A. Naseem. 2017. Creating "Invited" Spaces for Counter-Radicalization and Counter-Extremism Education. Diaspora, Indigenous, and Minority Education, 11(1), 6-16. https://doi.org/10.1080/15595692.2016.1258695 
Borum, R., and T. D. Patterson. 2019. Juvenile Radicalization Into Violent Extremism: Investigative and Research Perspectives. Journal of the American Academy of Child and Adolescent Psychiatry, 58(12), 1142-1148. https://doi.org/10.1016/j.jaac.2019.07.932

Bos, K. van den. 2020. Unfairness and Radicalization. Annual Review of Psychology, 71(1), 563-588. https://doi.org/10.1146/annurev-psych-010419050953

Campbell, J. C. and G. H. Jansen. 1980. Militant Islam. In Foreign Affairs (Vol. 58). https://doi.org/10.2307/20040558

Cohen, S. J., A. Kruglanskib, M. J. Gelfand, D. Webber, and R. Gunaratna. 2018. Al-Qaeda's propaganda decoded: A psycholinguistic system for detecting variations in terrorism ideology. Terrorism and Political Violence, 30(1), 142-171. https://doi.org/10.1080/09546553.2016.1165214

Crone, M. 2016. Radicalization revisited: Violence, politics and the skills of the body. International Affairs, 92(3), 587-604. https://doi.org/10.1111/14682346.12604

Doosje, B., F. M. Moghaddam, A. W. Kruglanski, A. De Wolf, L. Mann, and A. R. Feddes. 2016. Terrorism, radicalization and de-radicalization. Current Opinion in Psychology, 11(October), 79-84.

https://doi.org/10.1016/j.copsyc.2016.06.008

Eerten, J.-J. Van, B. Doosje, E. Konijn, B. De Graaf, M. De, G. Colophon, and B. Doosje. 2017. The role of counter-narratives in prevention of radicalization and de-radicalization. (September), 152. Retrieved from https://www.wodc.nl/binaries/2607_Volledige_Tekst_tcm28-286136.pdf

Ferguson, N., and James W McAuley. 2019. Radicalization or Reaction: Understanding Engagement in Violent Extremism in Northern Ireland. Political Psychology, O(0), 1-16. https://doi.org/10.1111/pops.12618

Fortier, A. M. 2008. Multicultural horizons: Diversity and the limits of the civil nation. In Multicultural Horizons: Diversity and the Limits of the Civil Nation. https://doi.org/10.4324/9780203935705

Fuad, M. 2004. Islam, modernity and Muhammadiyah's educational Programme. Inter-Asia Cultural Studies, 5(3), 400-414. https://doi.org/10.1080/1464937042000288697

Greenberg, K. J. 2016. Counter-Radicalization via the Internet. Annals of the American Academy of Political and Social Science, 668(1), 165-179. https://doi.org/10.1177/0002716216672635

Holt, T. J., Freilich, J. D., Chermak, S. M., Mills, C., and Silva, J. 2019. Loners, 
Colleagues, or Peers? Assessing the Social Organization of Radicalization. American Journal of Criminal Justice, 44(1), 83-105. https://doi.org/10.1007/s12103-018-9439-5

Jensen, M. A., A. Atwell Seate, and P.A. James. 2018. Radicalization to Violence: A Pathway Approach to Studying Extremism. Terrorism and Political Violence, 1-24. https://doi.org/10.1080/09546553.2018.1442330

Khosrokhavar, F. 2017. Radicalization, Why Some People Chooce The Path of Violence.

Klausen, J., S. Campion, N. Needle, G. Nguyen, and R. Libretti. 2016. Research Note: Toward a Behavioral Model of "Homegrown" Radicalization Trajectories. Studies in Conflict and Terrorism, 39(1), 67-83. https://doi.org/10.1080/1057610X.2015.1099995

Klausen, J., Libretti, R., Hung, B. W. K., and Jayasumana, A. P. 2018. Radicalization Trajectories: An Evidence-Based Computational Approach to Dynamic Risk Assessment of "Homegrown" Jihadists. Studies in Conflict and Terrorism, O(0), 1-28. https://doi.org/10.1080/1057610X.2018.1492819

Kruglanski, A., K. Jasko, D. Webber, M. Chernikova, and Molinario, E. 2018. The making of violent extremists. Review of General Psychology, 22(1), 107-120. https://doi.org/10.1037/gpr0000144

Kruglanski, A. W., Gelfand, M. J., Bélanger, J. J., Sheveland, A., Hetiarachchi, M., and Gunaratna, R. 2014. The psychology of radicalization and deradicalization: How significance quest impacts violent extremism. Political Psychology, 35(SUPPL.1), 69-93.

https://doi.org/10.1111/pops.12163

McCauley, C., and Moskalenko, S. 2008. Mechanisms of political radicalization: Pathways toward terrorism. Terrorism and Political Violence, 20(3), 415433. https://doi.org/10.1080/09546550802073367

Misiak, B., J. Samochowiec, K. Bhui, M. Schouler-Ocak, H. Demunter, L. Kuey, G. Dom. 2019. A systematic review on the relationship between mental health, radicalization and mass violence. European Psychiatry, 56, 51-59. https://doi.org/10.1016/j.eurpsy.2018.11.005

Neumann, K., F. Arendt, and P. Baugut. 2018. News and Islamist Radicalization Processes: Investigating Muslims' Perceptions of Negative News Coverage of Islam. Mass Communication and Society, 5436, 1-26. https://doi.org/10.1080/15205436.2018.1430832

Pemberton, P. L. 1952. Sociology of religion. Journal of the American Academy of Religion, 20(1), 27-29. https://doi.org/10.1093/jaarel/20.1.27

Porta, D. Della. 2018. Radicalization: A Relational Perspective. Annual Review of Political Science, 21(1), 461-474. https://doi.org/10.1146/annurev-polisci- 
Komariah: Radicalization: The

Misconception of Religious Practices in

Diversity

042716-102314

Schwartz, D. L. 2016. Discourses of Religious Violence and Christian Charity: The Christianization of Syria in Jacob of Sarug's On the Fall of the Idols. In Motions of Late Antiquity: Essays on Religion, Politics, and Society in Honour of Peter Brown (pp. 129-149).

Sharma, R., and S. Monteiro. 2016. Creating Social Change: The Ultimate Goal of Education for Sustainability. International Journal of Social Science and Humanity, 6(1), 72-77. https://doi.org/10.7763/IJSSH.2016.V6.621

Sheffield, Eric C.. 2016. Toward Radicalizing Community Service Learning. Vol 51 (1) 45-56.

https://doi.org/10.1080/00131946.2014.983637

Sieckelinck, S., E. Sikkens, M. Van San, S. Kotnis, and M. De Winter. 2017. Transitional Journeys Into and Out of Extremism. A Biographical Approach.

Studies in Conflict and Terrorism, 0731(November), 1-21. https://doi.org/10.1080/1057610X.2017.1407075

Soliman, A., T. Bellaj, and M. Khelifa. 2016. An integrative psychological model for radicalism: Evidence from structural equation modeling. Personality and Individual Differences, 95, 127-133.

https://doi.org/10.1016/j.paid.2016.02.039

Speckhard, A., and A. S. H. A. Jkovci. 2018. The Balkan Jihad Recruitment to Violent Extremism and Issues Facing Returning Foreign Fighters in Kosovo and Southern Serbia ANNE. Vol 101(2)

Webber, D., and A. W. Kruglanski,. 2018. The social psychological makings of a terrorist. Current Opinion in Psychology, 19, 131-134. https://doi.org/10.1016/j.copsyc.2017.03.024 